\title{
PEMBERDAYAAN IBU-BU RUMAH TANGGA MISKIN MELALUI INKUBASI USAHA MANDIRI DI KECAMATAN BENOWO KOTA SURABAYA
}

\author{
Trisa Indrawati ${ }^{1}$, Karlin ${ }^{2}$ \\ ${ }^{1,2}$ Universitas Wijaya Putra \\ trisaindrawati@uwp.ac.id
}

\begin{abstract}
Abstrak
Kelompok miskin di Kota Surabaya termasuk kategori kemiskinan perkotaan. Beban orang miskin di perkotaan akan lebih berat daripada beban orang miskin di perdesaan karena menghadapi persaingan hidup yang sangat keras di tengah-tengah pembangunan perkotaan dan kalah bersaing dalam kesempatan lapangan pekerjaan, mereka juga harus menanggung biaya hidup yang sangat mahal di kota. Oleh karena itu, kelompok miskin di perkotaan akan kesulitan memenuhi kebutuhan dasar (basic need) nya agar bisa hidup layak. Untuk itu diperlukan adanya program terpadu untuk penanggulangan kemiskinan di kota Surabaya. Tujuan program ini adalah untuk memberdayakan masyarakat miskin di Kecamatan Benowo Kota Surabaya, meningkatkan ketrampilan usaha mandiri masyarakat miskin di Kecamatan Benowo Kota Surabaya dan menambah penghasilan masyarakat miskin di Kecamatan Benowo Kota Surabaya. Metode pelaksanaan program ini melalui; Identifikasi data calon peserta pemberdayaan pelatihan , penyuluhan Motivasi, Testimoni dan Pembentukan Kelompok Usaha Bersama, Pelatihan Ketrampilan Produksi, Pelatihan Manajemen Usaha dan pendampingan Manajemen Usaha. Hasil pelaksanaan program antara lain; Sosialisasi Program dan Perkenalan Narasumber, Pelatihan Motivasi Wirausaha "Mengungkap Rahasia Berwirausaha dengan Cara Termudah, dan Cepat Menghasilkan” (Awal Program), Penjelasan Teknis Program Inkubasi dan Tata Tertib Kegiatan Inkubasi Usaha Mandiri, Pelatihan Keterampilan Membuat Sagon Semanggi, Pelatihan Manajemen Pemasaran Online - FB Marketing dan Instagram Marketing, Pelatihan Manajemen Pemasaran dan Tata Rupa, Pelatihan Manajemen Keuangan - Cara Menghitung Biaya, Menentukan Harga dan Menghindari Kerugian Usaha Agar Selalu Untung, Pelatihan Manajemen Organisasi dan SDM, Penyuluhan Legalitas Usaha dan Lingkungan dan Penyuluhan Akses Permodalan, Pelatihan Motivasi Wirausaha - "Mental Block Coach and Solution" (Pertengahan Program), Pelatihan Motivasi Wirausaha - "Yes! Aku Berhasil (=Bisa)" (Akhir Program) dan di akhiri program pendampingan..
\end{abstract}

Kata Kunci : Masyarakat Miskin Perkotaan, Inkubasi Usaha Mandiri

\section{PENDAHULUAN}

Surabaya merupakan kota Metropolitan terbesar kedua di Indonesia yang memiliki magnet penarik bagi penduduk daerah penyangga terutama wilayah perdesaan di sekitarnya. Seiring waktu, dengan makin bertambahnya jumlah penduduk alami dan pendatang maka Surabaya menjadi kota yang sangat padat dan bermunculanlah perkampungan kumuh dan kebutuhan untuk perumahan kian meningkat. Menurut data Pemkot Surabaya, kebutuhan lahan perumahan tahun 20013-2013 mencapai $17.593 \mathrm{Ha}$ (53,8\% dari total luas Surabaya) dengan jumlah kebutuhan permukiman mencapai 556.542 unit. Pembangunan rumah susun sebagai

$$
\text { Ekonomi, Sosial dan Budaya }
$$


alternative hunian bagi masyarakat berpenghasilan rendah telah dilaksanakan oleh Pemkot Surabaya beberapa tahun terakhir. Namun demikin keberadaan rusun paska huni cenderung menjadi kumuh dan menambah kekumuhan lingkungan. Oleh karenanya terdapat dua kebijakan terkait yang kini dilaksanakan yaitu pembangunan kembali rusun dengan konsep re-development dan kerjasama dengan kementerian untuk pemberdayaan masyarakat di kampung kumuh. Program pemberdayaan masyarakat melalui pelatihan keterampilan dasar merupakan program pemberdayaan dengan bentuk pelatihan keterampilan dasar yang terbagi menjadi beberapa jenis pelatihan dasar yang dilaksanakan. Dalam pelaksanaannya juga terdapat mekanisme operasional yang tertuang dalam pedoman pelaksanaan pemberdayaan ekonomi bagi keluarga miskin.

Pemerintah Kota Surabaya merupakan salah satu Kota yang melaksanakan program penanggulangan kemiskinan dengan berbasis pemberdayaan masyarakat dalam peningkatan kualitas hidup masyarakatnya. Rancangan pemberdayaan masyarakat ini didesain sebagai pengembangan potensi yang dimiliki oleh kelompok masyarakat miskin dan kemampuan potensi yang dimiliki oleh para stakeholders seperti organisasi pemerintah, organisasi non-pemerintah, dan masyarakat itu sendiri. Salah satu program Pemerintah Kota Surabaya dalam upaya penanggulangan kemiskinan berbasis pemberdayaan adalah melalui pelatihan keterampilan dasar bagi keluarga miskin.

Dinas Pengendalian Penduduk, Pemberdayaan Perempuan dan Perlindungan Anak sebagai salah satu SKPD yang bertanggung jawab dalam pemberdayaan masyarakat bermaksud mengadakan pelatihan ketrampilan dasar bagi penghuni rusun. Pelatihan keterampilan dasar bagi keluarga miskin merupakan salah satu program penanggulangan kemiskinan dengan memberdayakan masyarakat dalam meningkatkan ketahanan ekonomi keluarga yang tinggal di rusun di Kota Surabaya. Selain itu,, pelatihan keterampilan dasar bagi keluarga rusun ini juga bertujuan untuk dapat meningkatkan tumbuhnya kelompokkelompok usaha baru di lingkungan rusun. Dalam pelaksanaannya, Para peserta dalam program pelatihan keterampilan dasar akan diberi bekal pelatihan dan juga akan mendapatkan pendampingan sehingga para peserta pelatihan keterampilan dasar akan tergabung dalam kelompok swadaya masyarakat (KSM) yang kemudian akan mendapatkan pendampingan serta bantuan peralatan kerja dan fasilitasi pemasaran agar bisa berproduksi dan memasarkan produknya secara mandiri.

\section{METODE}

Metode pelaksanaan kegiatan ini antara lain; 1). Identifikasi, meliputi kegiatan survey pengumpulan data calon peserta pemberdayaan pelatihan; 2). Penyuluhan Motivasi Dan Pembentukan Kelompok Usaha Bersama, meliputi kegiatan Open Mind tentang Manfaat dan Keuntungan memiliki Usaha sendiri, dilanjutkan dengan testimoni pengalaman dari wirausahawan yang berhasil hasil binaan DP5a dan diakhiri dengan pembentukan kelompok usaha bersama; 3). Pelatihan Ketrampilan Produksi, meliputi kegiatan pelatihan ketrampilan usaha produksi, sesuai bidang usaha yang diminati oleh peserta; 4). Pelatihan Manajemen Usaha, meliputi kegiatan pelatihan manajemen usaha, dalam bidang manajemen pemasaran, manajemen organisasi \& SDM, manajemen, manajemen keuangan, penyuluhan legalitas usaha dan lingkungan serta penyuluhan akses permodalan; dan 5). Pendampingan Manajemen Usaha, meliputi kegiatan pendampingan manajemen produksi, manajemen pemasaran dan manajemen keuangan

\section{HASIL DAN PEMBAHASAN}

\section{Program Inkubasi Usaha Mandiri}

Program Fasilitasi Inkubasi Usaha Mandiri ini terdiri dari kegiatan pelatihan dan pendampingan yang didahului dengan Kegiatan Sosialisasi Program bagi Calon peserta Inkubasi Usaha Mandiri. Adapun jenis-jenis kegiatan Inkubasi Usaha Mandiri sebagai berikut :

1. Sosialisasi Program dan Perkenalan Narasumber

2. Pelatihan Motivasi Wirausaha "Mengungkap Rahasia Berwirausaha dengan Cara Termudah dan Cepat Menghasilkan" (Awal Program)

3. Penjelasan Teknis Program Inkubasi dan Tata Tertib Kegiatan Inkubasi Usaha Mandiri

4. Pelatihan Keterampilan

$$
\text { Ekonomi, Sosial dan Budaya }
$$


a. Pelatihan Membuat Sagon Semanggi di Kecamatan Benowo Surabaya

b. Pelatihan Membuat Stick Semanggi di Kecamatan Lakarsantri Surabaya

c. Pelatihan Membuat Kembang Goyang Semanggi di Kecamatan Pakal Surabaya

d. Pelatihan Membuat Peyek Semanggi di Kecamatan Sambikerep Surabaya

e. Pelatihan Membuat Lapis Kukus Semanggi di Kecamatan Tandes Surabaya

5. Pelatihan Manajemen Pemasaran Online - FB Marketing dan Instagram Marketing

6. Pelatihan Manajemen Pemasaran dan Tata Rupa

7. Pelatihan Manajemen Keuangan - Cara Menghitung Biaya, Menentukan Harga dan Menghindari Kerugian Usaha Agar Selalu Untung

8. Pelatihan Manajemen Organisasi dan SDM

9. Penyuluhan Legalitas Usaha dan Lingkungan dan Penyuluhan Akses Permodalan

10. Pelatihan Motivasi Wirausaha - "Mental Block Coach and Solution" (Pertengahan Program)

11. Pelatihan Motivasi Wirausaha - "Yes! Aku Berhasil (=Bisa)" (Akhir Program)

Setelah rangkaian pelatihan selesai kemudian dilanjutkan dengan pendampingan. Adapun jenis pendampingan yaitu :

1. Pendampingan Manajemen Produksi Konsultasi Proses dan Kualitas Produksi

2. Pendampingan Manajemen Pemasaran dan Tata Rupa - Konsultasi Penetrasi Pasar dan Kemasan

3. Pendampingan Manajemen Pemasaran Online - Konsultasi Pemasaran Melalui FB dan Instagram

4. Pendampingan Manajemen Keuangan Konsultasi Pencatatan Keuangan dan Menghitung Harga Pokok Penjualan

5. Pendampingan Motivasi Wirausaha

6. Pendampingan SDM

7. Pendampingan Legalitas Usaha - Konsultasi Pengurusan Usaha

8. Pendampingan Akses Permodalan Konsultasi Permodalan

9. Penutupan dan Evaluasi untuk Peserta
Pelatihan dilaksanakan seminggu 1-2 kali pertemuan dan dilanjutkan dengan kegiatan pendampingan dimasing-masing kecamatan seminggu sekali.

\section{Program Inkubasi Usaha Mandiri di Kecamatan Benowo Surabaya}

Program Fasilitasi Inkubasi Usaha Mandiri ini disosialisasikan kepada peserta di Kecamatan Benowo pada hari Selasa, 13 Maret 2018 bertempat di Aula Kantor Kecamatan Benowo Surabaya. Acara Sosialisasi ini dihadiri oleh Perwakilan dari DP5A, Perwakilan dari Kecamatan Benowo dan Tim Narasumber dari Universitas Wijaya Putra Surabaya yaitu Karlin, SE, M.Ak, Andi Iswoyo, SE, MM, Yanuar Fauzuddin, SE, MM dan Agung Bayu Murti, SE, MSE. Kegiatan Sosisalisasi Program Inkubasi Usaha Mandiri ini dihadiri oleh 21 orang peserta.

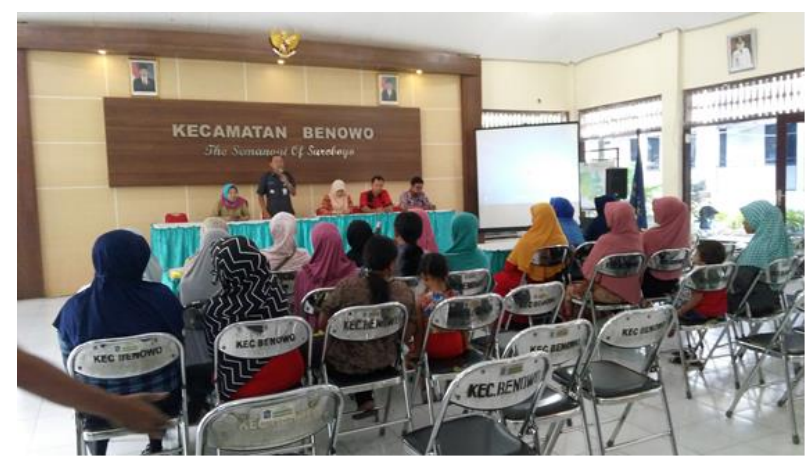

Gambar 1 Sosialisasi Program dan Perkenalan Narasumber

\section{Pelatihan Inkubasi Usaha Mandiri}

Kegiatan pelatihan Fasilitasi Inkubasi Usaha Mandiri ini dilaksanakan Aula Kantor Kecamatan Benowo. Peserta pelatihan merupakan ibu-ibu dengan penghasilan keluarga dibawah Upah Minimum Kota (UMK) dan tercatat sebagai warga Kecamatan Benowo Surabaya.

\section{Pelatihan Motivasi Wirausaha (Open Mind)}

Pelatihan Motivasi Wirausaha merupakan pelatihan yang bertujuan untuk menstimulus munculnya minat untuk berwirausaha. Pelatihan ini bersifat Open Mind yaitu mengedukasi peserta agar memiliki pikiran lebih terbuka terhadap peluang-

$$
\text { Ekonomi, Sosial dan Budaya }
$$


peluang meningkatkan penghasilan keluarga melalui wirausaha. Selain penyampaian materi motivasi didukung juga oleh Kesaksian (Testimoni) dari Ibu yang sudah sukses berwirausaha meskipun memulai usaha tanpa memiliki modal yang mencukupi dan akhirnya usahanya dapat berkembang dan sukses.

Pelatihan Motivasi Wirausaha di Kecamatan Benowo dilaksanakan pada hari Sabtu, 24 Maret 2018. Acara dimulai dengan Materi Motivasi Wirausaha "Mengungkap Rahasia Berwirausaha dengan Cara Termudah dan Menghasilkan Bagi IbuIbu" yang disampaikan oleh Karlin, SE, M.Ak selaku narasumber Motivasi. Pelatihan Motivasi ini dihadiri oleh 13 orang peserta.

Kesaksian (Testimoni) Wirausaha Sukses disampaikan oleh Ibu Sudarwi Yuliningsih dan Ibu Mamik. Ibu Sudarwi Yuliningsih merupakan Pengusaha Peyek, Brownies Kering, Egg Roll dan aneka Kue Kering lainnya yang memulai usaha karena terbelit hutang puluhan juta akibat melahirkan anak kembar prematur. Sementara Ibu Mamik adalah pengusaha Kerupuk Samiler Aneka Rasa yang memulai usaha karena ingin meningkatkan perekonomian keluarga.

Setelah peserta mendapatkan motivasi dan mendengarkan cerita kesaksian Ibu-Ibu yang menjadi Testimoni, peserta segera diajak untuk berperan aktif dalam program inkubasi ini. Penjelasan Teknis Program Inkubasi Usaha Mandiri dan Tata Tertib disampaikan oleh Bapak Andi Iswoyo, SE, MM selaku narasumber. Kemudian dilanjutkan dengan pembentukan kelompok sesuai dengan wilayah (tempat tinggal) terdekat untuk memudahkan anggota kelompok melakukan koordinasi dan produksi bersama.

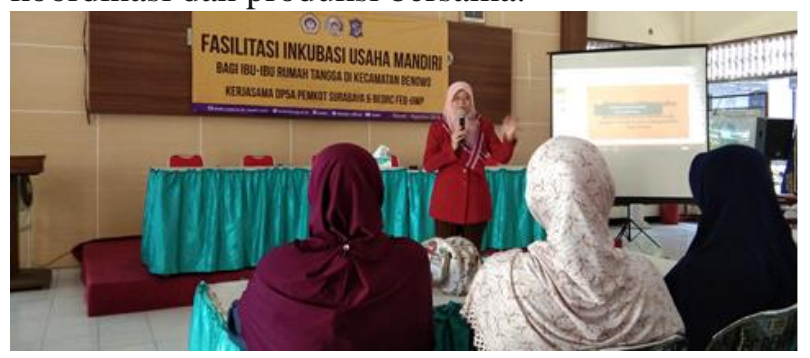

Gambar 2 Pelatihan Open Mind - Motivasi Wirausaha dan Testimoni

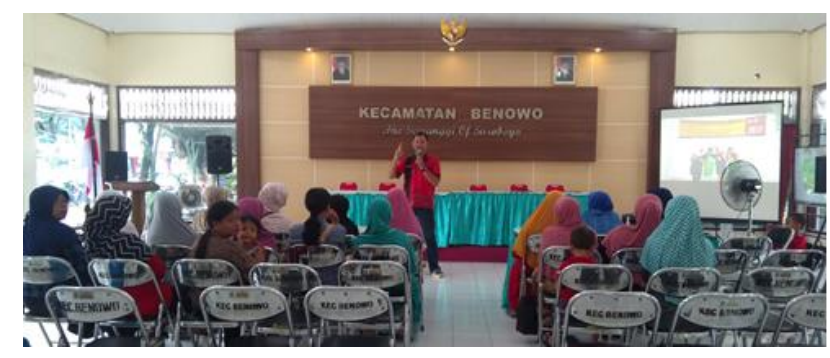

Gambar 3 Penjelasan Teknis Program Inkubasi Usaha Mandiri

\section{Pelatihan Keterampilan Membuat Sagon Semanggi}

Pelatihan Keterampilan bertujuan agar peserta memiliki keterampilan untuk membuat produk oleh-oleh yang dapat dijadikan sebagai usaha mandiri. Pelatihan Keterampilan ini mengajarkan untuk membuat Sagon Semanggi. Mengapa Sagon Semanggi? Karena Sagon Semanggi mudah proses pembuatannya dengan memanfaatkan peralatan yang sudah dimiliki oleh peserta. Bahan yang dibutuhkan juga mudah diperoleh dan harganya relatif murah. Penambahan bahan Semanggi agar produk tersebut menjadi ciri khas Kota Surabaya. Produk Sagon bisa saja diproduksi oleh daerah lain namun jika Sagon Semanggi akan tetap membawa nama Kota Surabaya karena Semanggi merupakan salah satu icon Surabaya yang terkenal dengan makanan khas Semanggi Suroboyo.

Pelatihan Keterampilan dilaksanakan pada hari Sabtu, 31 Maret 2018 bertempat di Aula Kantor Kecamatan Benowo Surabaya. Pelatihan Membuat Sagon Semanggi ini dihadiri oleh 9 orang peserta dan narasumber Ibu Sudarwi Yuliningsih dan Andi Iswoyo, SE, MM.

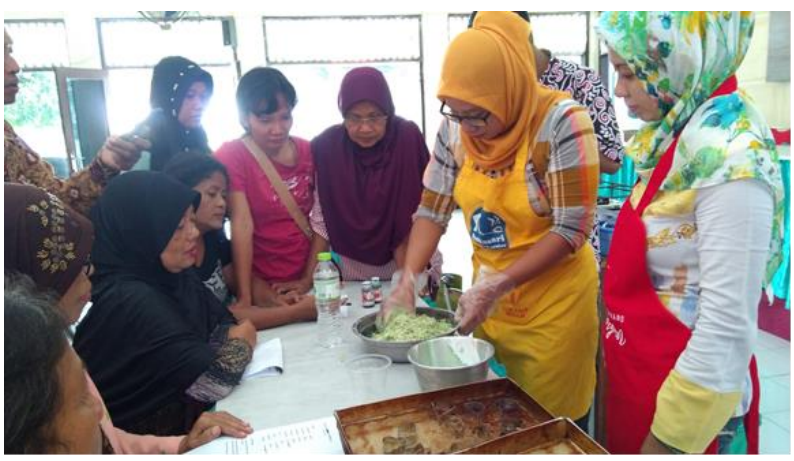

Gambar 4 Pelatihan Keterampilan Membuat Sagon Semanggi

Pelatihan Manajemen Pemasaran Online - FB Marketing dan Instagram Marketing

Pelatihan Manajemen Pemasaran Online ditujukan agar peserta mampu memanfaatkan media Ekonomi, Sosial dan Budaya 
online untuk memasarkan produk Sagon Semanggi. Materi Pemasaran online dikemas sederhana namun powerful untuk mendapatkan order dengan memberikan trik-trik update status di Facebook maupun Instagram secara tertarget.

Pada Pelatihan Manajemen Pemasaran Online peserta juga belajar menawarkan produk dengan kalimat-kalimat Hypnoselling agar mudah mendapatkan order lebih banyak dan pembeli puas.

Pelatihan dilaksanakan pada hari Rabu, 4 April 2018 bertempat di Aula Kantor Kecamatan Benowo Surabaya. Peserta yang hadir sebanyak 9 orang dan sebagai narasumber Karlin, SE, M.Ak.

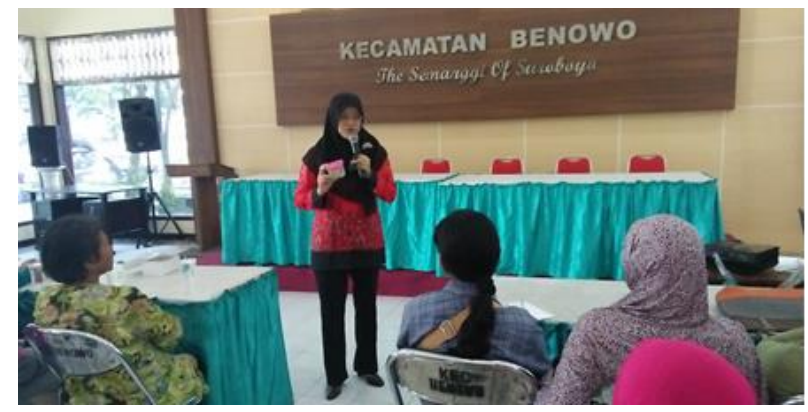

Gambar 5 Pelatihan Manajemen Pemasaran Online - FB Marketing dan Instagram Marketing

Pelatihan Manajemen Pemasaran dan Tata Rupa

Pelatihan Manajemen Pemasaran dan Tata Rupa ini bertujuan untuk mengedukasi peserta pelatihan agar memahami cara melakukan pemasaran secara baik dan benar. Kemampuan untuk melakukan pemasaran merupakan salah satu bagian penting dalam wirausaha.

Pelatihan dilaksanakan pada hari Rabu, 11 April 2018 di Aula Kantor Kecamatan Benowo dihadiri oleh 4 orang peserta dan sebagai narasumber Agung Bayu Murti, SE, MSE.

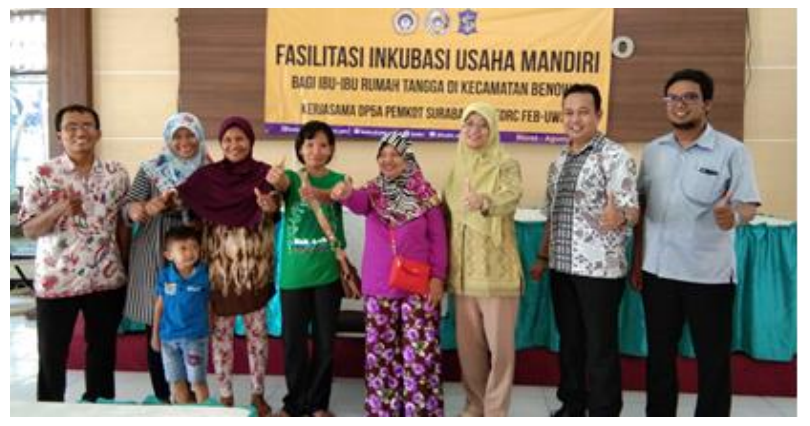

Gambar 6 Pelatihan Manajemen Pemasaran dan Tata Rupa

\section{Pelatihan Manajemen Organisasi dan SDM}

Pelatihan Manajemen Organisasi dan SDM dengan judul "Kerja Santai Berkualitas" merupakan pelatihan yang bertujuan agar peserta mampu membagi tugas anggota kelompok dan masingmasing mampu menjalankan tugasnya dengan baik tanpa merasa iri dengan anggota lain. Apabila omset terus meningkat dan mereka butuh untuk mempekerjakan orang lain untuk membantu produksi atau pemasaran, diharapkan mampu mengorganisir orang yang dipekerjakan tersebut dengan baik.

Pelatihan Manajemen Organisasi dan SDM dilaksanakan pada hari Sabtu, 14 April 2018 dengan Narasumber Yanuar Fauzuddin, SE, MM. Pelatihan Manajemen Organisasi dan SDM dihadiri oleh 6 orang peserta.

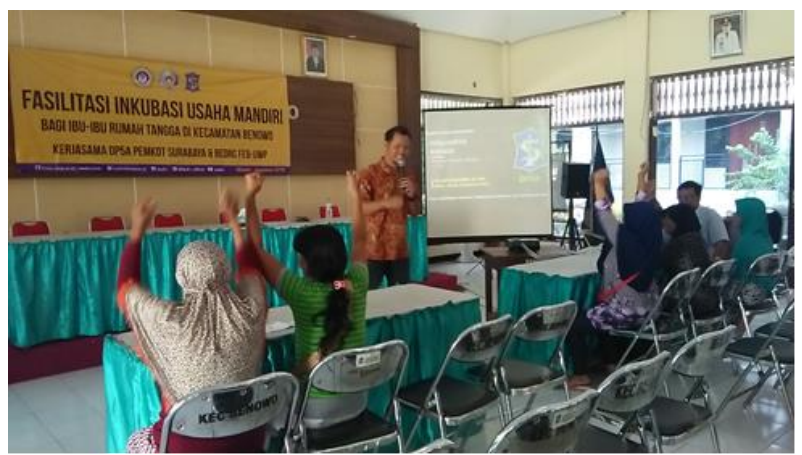

Gambar 7 Pelatihan Manajemen Organisasi dan SDM

\section{Pelatihan Manajemen Keuangan}

Pelatihan Manajemen Keuangan dengan judul "Cara Menghitung Biaya, Menentukan Harga dan Menghindari Kerugian Usaha Agar Selalu Untung". Peserta mendapat pengetahuan dasar tentang manjemen keuangan sehingga peserta mampu menentukan harga jual produknya, mampu melakukan pencatatan sederhana dan dapat menghitung keuntungannya.

Pelatihan Manajemen Keuangan dilaksanakan pada hari Rabu, 18 April 2018 bertempat di Aula Kecamatan Benowo Surabaya. Pelatihan Manajemen Keuangan ini dihadiri oleh 5 
orang peserta dan Trisa Indrawati, SE, MM sebagai narasumber.

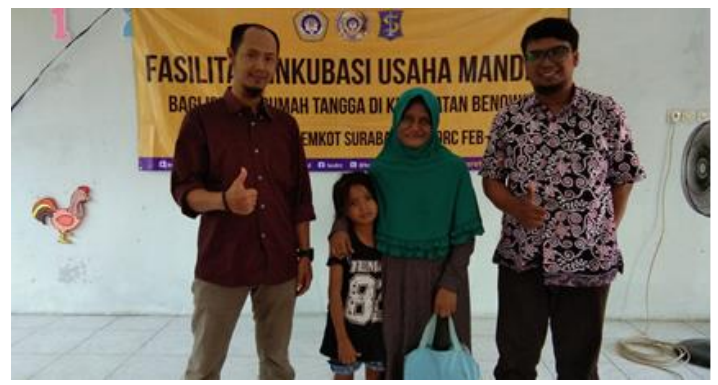

Gambar 8 Pelatihan Manajemen Keuangan

\section{Pelatihan Motivasi Wirausaha - "Mental Block Coach and Solution"}

Pelatihan Motivasi Wirausaha "Mental Block Coach and Solution" diberikan pada saat peserta sudah mulai praktek membuat Sagon Semanggi dan memasarkannya. Pada tahap ini peserta mulai mengalami rasa malu untuk menawarkan, rasa takut ditolak dan perasaan lainnnya yang dapat menghambat proses pemasaran. Pelatihan Motivasi ini sebagai solusi agar peserta mampu mengatasi ketakutan-ketakutannya dan tetap berusaha produksi dan mencari pelanggan.

Pelatihan Motivasi Wirausaha ini dilaksanakan pada hari Rabu, 25 April 2018 bertempat di Aula Kecamatan Benowo Surabaya. Pelatihan Motivasi ini dihadiri oleh 3 orang dengan narasumber Karlin, SE, M.Ak

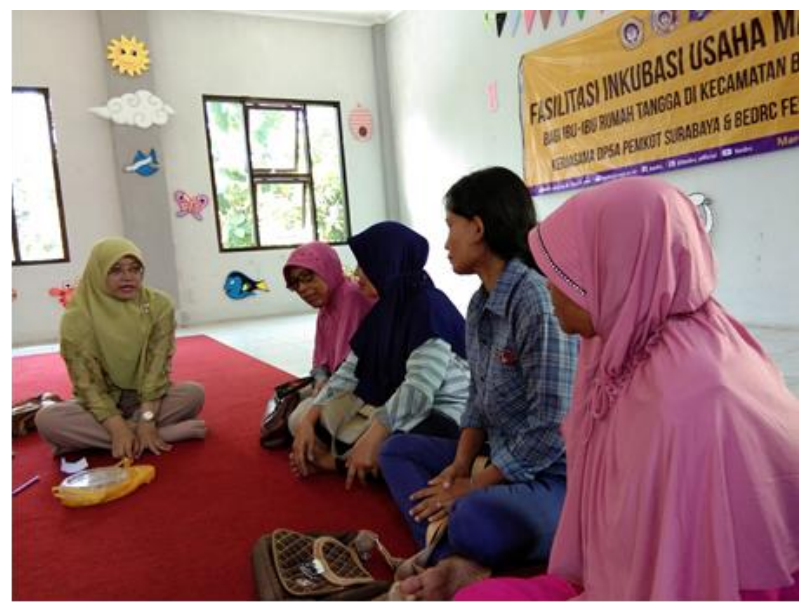

Gambar 9 Pelatihan Motivasi Wirausaha - "Mental Block Coach and Solution"

\section{Penyuluhan Legalitas Usaha dan Lingkungan}

Penyuluhan Legalitas Usaha dan Lingkungan merupakan edukasi bagi peserta untuk mengetahui cara mengurus perijinan atau legalitas bagi produk yang telah diproduksi oleh peserta pelatihan. Legalitas sangat penting untuk mengembangkan usaha agar tidak terkendala saat dipasarkan ke wilayah yang lebih luas.

Penyuluhan Legalitas Usaha dan Lingkungan dilaksanakan pada hari Sabtu, 28 April 2018, dihadiri oleh 4 orang peserta dan narasumber Andi Iswoyo, SE, MM.

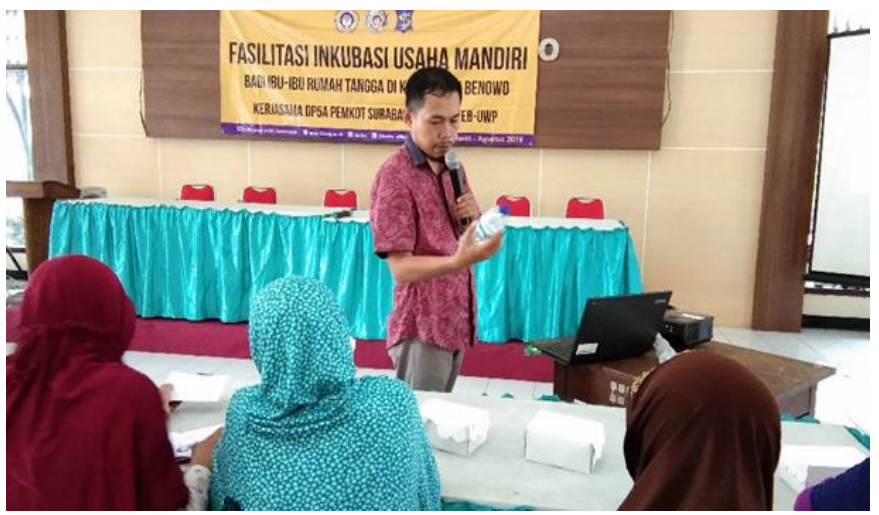

Gambar 10 Penyuluhan Legalitas Usaha dan Lingkungan

\section{Penyuluhan Akses Permodalan}

Penyuluhan Akses Permodalan merupakan edukasi bagi peserta untuk mendapatkan permodalan dalam rangka pengembangan usaha. Peserta distimulus untuk mendapatkan ide permodalan tanpa bunga sebagai modal awal memulai usaha.

Pelaksanaan pelatihan ini pada hari Sabtu, 28 April 2018 bertempat di Aula Kantor Kecamatan Benowo Surabaya. Penyuluhan ini dihadiri oleh 4 orang peserta dan sebagai narasumber Dwi Lesno Panglipursari, SE, MM.

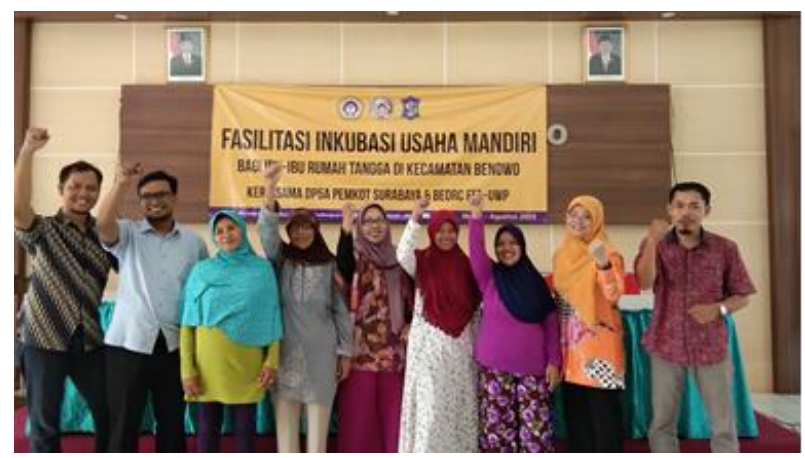

Ekonomi, Sosial dan Budaya 
Gambar 11 Penyuluhan Akses Permodalan

\section{Pelatihan Motivasi Wirausaha - "Yes Aku Berhasil"}

Pelatihan Motivasi Wirausaha yang ketiga diberikan sebelum penutupan untuk meningkatkan motivasi peserta. Pada materi motivasi yang terakhir ini peserta diajak untuk lebih mengenali potensi yang dimilikinya dan merupakan peserta yang unggul terbukti bahwa mampu bertahan menghadiri pelatihan dan pendampingan secara keseluruhan dan mampu beromset.

Kegiatan Pelatihan Motivasi Wirausaha "Yes Aku Berhasil" (=Bisa) dilaksanakan pada hari Rabu, 15 Agustus 2018 dihadiri oleh 5 orang peserta dan sebagai narasumber Karlin, SE, M.Ak.

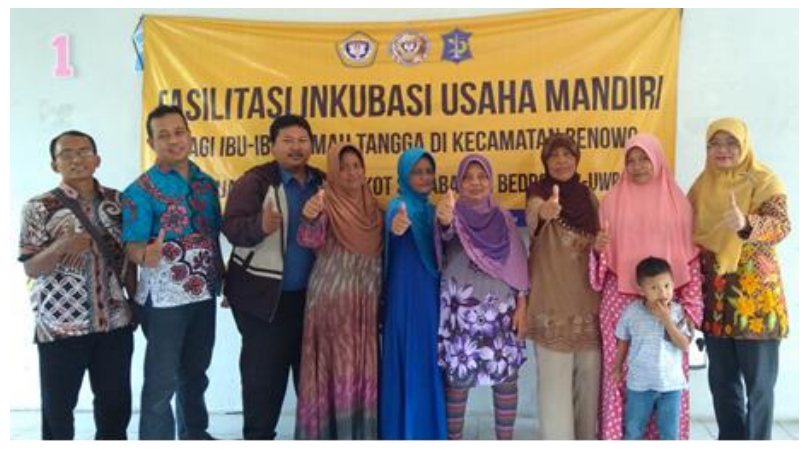

Gambar 12 Pelatihan Motivasi Wirausaha - "Yes Aku Berhasil"

\section{Pendampingan Inkubasi Usaha Mandiri}

Setelah rangkaian pelatihan selesai kemudian dilanjutkan dengan kegiatan Pendampingan Inkubasi Usaha Mandiri. Pendampingan ini memfasilitasi peserta agar dapat konsultasi terkait hasil mereka mempraktekkan ilmu yang sudah diberikan pada beberapa pelatihan sebelumnya. Disamping menerima konsultasi para narasumber pendampingan juga memberikan tips dan trik untuk mengatasi permasalahanpermasalahan yang dihadapi peserta.

\section{Pendampingan Manajemen Pemasaran dan Tata Rupa}

Pendampingan Manajemen Pemasaran dan Tata Rupa merupakan media konsultasi terkait pemasaran dan kemasana produk. Setelah peserta belajar dan praktek untuk memasarkan produknya tentunya mengalami beberapa pengalaman yang berbeda, pengalaman ini yang menjadai bahan konsultasi dengan tim narasumber Pendampingan Pemasaran dan Tata Rupa. Para narasumber pendampingan ini akan memberikan solusi terkait permasalahan pemasaran yang dihadapi oleh peserta. Bagi peserta yang penjualannnya sudah meningkat diberi kesempatan untuk berbagi pengalaman dalam melakukan penjualan produk sehingga dapat menjadi alternatif penyelesaian dari kendala pemasaran yang dihadapi peserta.

Kegiatan Pendampingan Manajemen Pemasaran dan Tata Rupa dilaksanakan pada hari Rabu, 02 Mei 2018 dihadiri oleh 4 orang peserta dan sebagai narasumber Agung Bayu Murti, SE, MSE dan Yanuar Fauzuddin SE, MM.

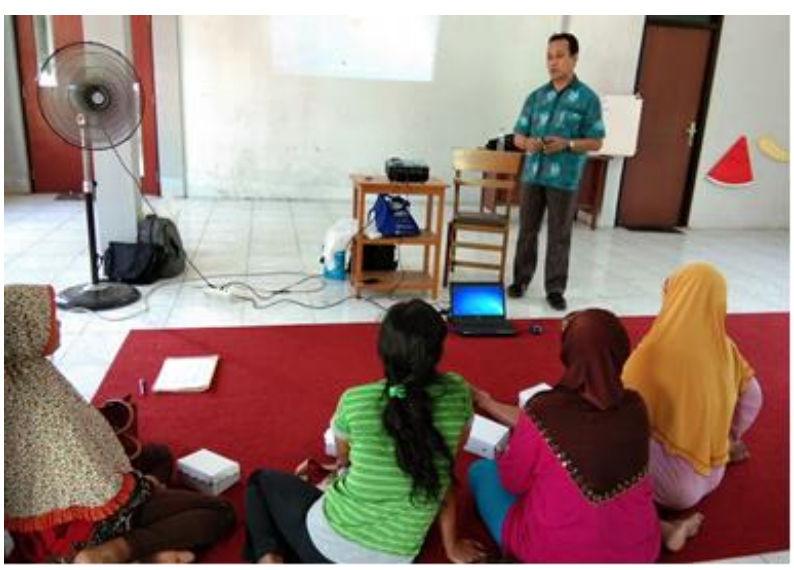

Gambar 13 Pendampingan Manajemen Pemasaran dan tata Rupa

\section{Pendampingan Manajemen Produksi}

Pendampingan Manajemen Produksi merupakan waktu yang disediakan oleh narasumber untuk konsultasi terhadap permasalahanpermasalahan yang dihadapi oleh peserta saat melakukan proses produksi. Pengalaman praktek produksi awal akan menimbulkan banyak permasalahan yang perlu untuk dikonsultasikan dengan narasumber.

Kegiatan Pendampingan Produksi dilaksanakan pada hari Rabu, 9 Mei 2018 dihadiri oleh 4 orang peserta dan sebagai narasumber Ibu Sudarwi Yuliningsih \& Karlin, SE, M.Ak.

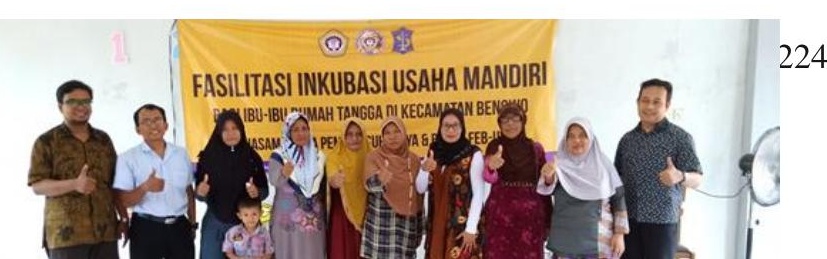


Gambar 14 Pendampingan Manajemen Produksi

\section{Pendampingan Manajemen Keuangan}

Pendampingan Manajemen Keuangan bertujuan untuk memberikan pengarahan secara langsung kepada peserta yang masih kesulitan dalam membuat pencatatan keuangan. Bagi peserta yang sudah mampu membuat pencatatan juga dikoreksi hasilnya agar tidak terjadi kesalahan.

Kegiatan Pendampingan Manajemen Keuangan dilaksanakan pada hari Kamis, 12 Juli 2018 dihadiri oleh 1 orang peserta dan sebagai narasumber Dr. Taudlikhul Afkar, S.Pd.,M.Pd dan Yanuar Fauzuddin, SE, MM.

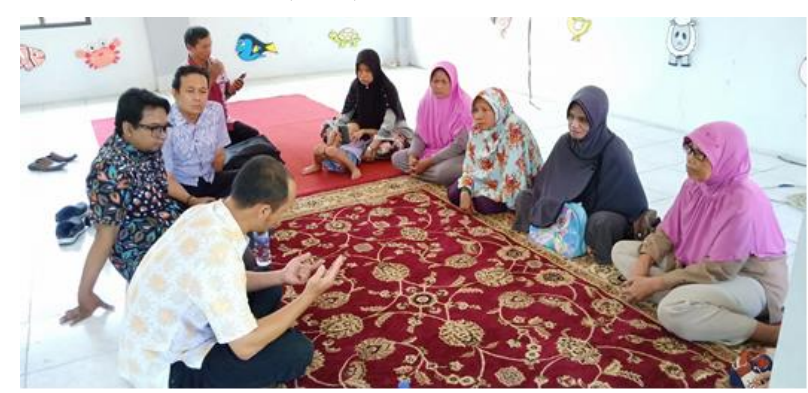

Gambar 15 Pendampingan Manajemen Keuangan

\section{Pendampingan Pemasaran Online}

Pendampingan Pemasaran online bertujuan untuk menerima konsultasi peserta terkait pemanfaatan media online sebagai media pemasaran produk. Pada umumnya mereka melakukan pengenalan produk melalui Update Status Whats App dan Facebook Profile.

Kegiatan Pendampingan Pemasaran Online dilaksanakan pada hari Kamis, 5 Juli 2018 dihadiri 4 orang peserta dan sebagai narasumber Karlin, SE, M.Ak dan Yanuar Fauzuddin, SE, MM.

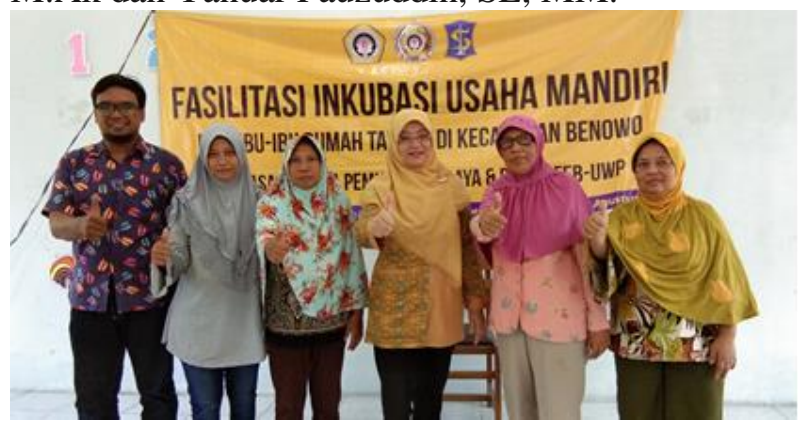

Gambar 16 Pendampingan Pemasaran Online

\section{Pendampingan Manajemen Organisasi dan Sumber Daya Manusia}

Pendampingan Manajemen Organisasi dan SDM ini bertujuan agar peserta menyampaikan keberhasilan maupun kendala yang dihadapi dalam menjalankan usaha secara kelompok maupun individu. Para narasumber perlu memastikan kemampuan peserta dalam menerapkan ilmu tentang Manajemen Organisasi dan SDM dalam kelompoknya masing-masing.

Kegiatan Pendampingan Manajemen Organisasi dan Sumber Daya Manusia dilaksanakan pada hari Kamis, 19 Juli 2018 dihadiri oleh 4 orang peserta selaku narasumber Hendrik Rizqiawan, SE, MM dan Aditya Surya Nanda, S.EI, M.SEI.

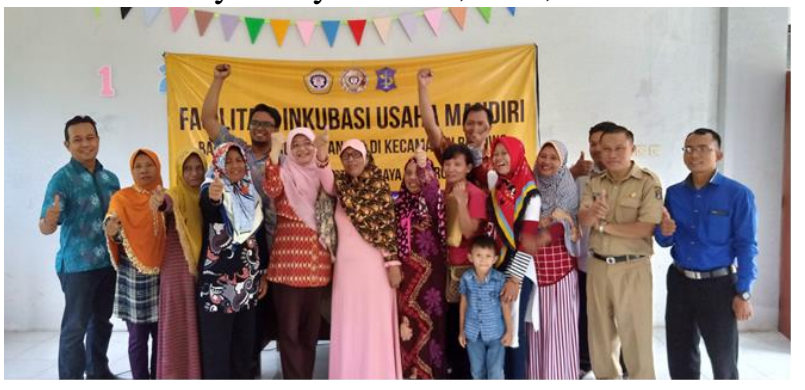

Gambar 17 Pendampingan Manajemen Organisasi dan Sumber Daya Manusia

\section{Pendampingan Motivasi}

Pendampingan Motivasi bertujuan untuk menerima konsultasi, lebih tepatnya adalah menerima curhat dari peserta. Saat mulai praktek produksi dan pemasaran beberapa kendala mulai dihadapi dan menimbulkan penurunan motivasi.

$$
\text { Kegiatan Pendampingan Motivasi }
$$

Wirausaha ini dilaksanakan pada hari Kamis, 26 Juli 2018 dihadiri oleh 4 orang peserta dan selaku narasumber Karlin, SE, M.Ak dan Agung Bayu Murti, SE, M.SE.

\section{Pendampingan Legalitas Usaha}

Pendampingan Legalitas Usaha bertujuan agar peserta dapat mempersiapkan kebutuhan terkait

Ekonomi, Sosial dan Budaya

1225 
pengurusan perijinan produk. Termasuk juga pendampingan terhadap kesadaran untuk tetap memperhatikan kebersihan lingkungan saat melakukan proses produksi. Kenyamanan lingkungan dan kebersihan lingkungan harus tetap diperhatikan. Proses produksi tidak boleh menyebabkan lingkungan menjadi kotor dan tercemar oleh limbah usaha peserta Inkubasi Usaha Mandiri.

Kegiatan Pendampingan Legalitas Usaha dilaksanakan pada hari Kamis, 02 Agustus 2018 dihadiri oleh 7 orang peserta dan sebagai narasumber Hendrik Rizqiawan, SE, MM dan Karlin, SE, M.Ak.

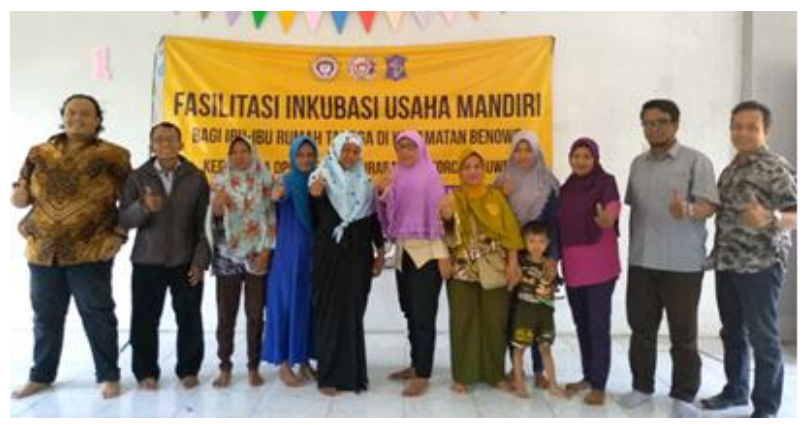

Gambar 19 Pendampingan Legalitas Usaha

\section{Pendampingan Akses Permodalan}

Pendampingan Akses Permodalan ini sebagai sarana untuk menerima konsultasi peserta terkait permodalan. Usaha yang baru dirintis tentunya lebih difokuskan pada modal yang sudah dimiliki oleh peserta berupa peralatan, Sumber Daya Manusia maupun modal berupa uang anggota kelompok usaha. Peserta diharapkan dapat memaksimalkan pemanfaatan modal yang sudah dimiliki untuk merintis usaha sebelum mereka memenuhi syarat untuk mengajukan pinjaman modal usaha kepada perbankkan maupun Koperasi.

Kegiatan Pendampingan Akses Permodalan dilaksanakan pada hari Kamis, 09 Agustus 2018 dihadiri oleh 6 orang peserta dan sebagai narasumber Dr. Taudlikhul Afkar, S.Pd.,M.Pd dan Yanuar Fauzuddin, SE, MM.

\section{Penutupan Kegiatan Inkubasi Usaha Mandiri}

Penutupan Kegiatan Inkubasi Usaha Mandiri dilaksanakan pada hari Selasa, 21 Agustus 2018 dihadiri oleh 7 orang peserta, perwakilan dari
DP5A, perwakilan dari Kecamatan Benowo dan tim narasumber.

\section{Identifikasi Penurunan Jumlah Peserta}

Pelatihan dan pendampingan Fasilitasi Inkubasi Usaha Mandiri secara umum berjalan baik dan lancar. Meskipun ada penurunan dari jumlah peserta yang terdaftar dengan jumlah peserta yang mengikuti pelatihan maupun pendampingan.

Beberapa narasumber melakukan identifikasi terhadap penyebab menurunnya kehadiran tersebut. Identifikasi dilakukan dengan cara menggali informasi dari peserta yang aktif melalui wawancara dan menghubungi peserta yang tidak aktif. Berikut ini beberapa faktor penyebabnya:

1. Bekerja, Beberapa peserta terkendala untuk menghadiri pelatihan karena kerja. Semula mereka berharap pelatihan diadakan pada hari libur atau diluar jam kerja. Karena pelatihan dilaksanakan pada jam kerja sehingga mereka tidak dapat menghadiri pelatihan

2. Mengasuh Anak atau Cucu, Peserta yang sudah mendaftar dan terkendala harus mengasuh anaknya yang masih balita atau Nenek yang mengasuh cucunya karena orang tuanya bekerja juga tidak bisa aktif menghadiri pelatihan, diantaranya ada yg tidak pernah hadir pelatihan dan ada yang hadir hanya sekali.

3. Mengantar Sekolah, peserta yang memiliki anak sekolah masih kecil terutama usia Taman Kanak - Kanak ( TK ) harus mengantarkan sekolah bahkan menunggunya hingga jam pulang sekolah sehingga tidak dapat menghadiri pelatihan

4. Lanjut Usia dan Kurang Sehat, Beberapa peserta sudah lanjut usia dan sering mengalami gangguan kesehatan. Termasuk juga Bu Yuliana merupakan salah satu peserta yang sangat antusias namun tidak dapat aktif hadir atau produksi karena harus sering kontrol ke dokter akibat penyakit komplikasi yang dideritanya. Meskipun sebenarnya usia $\mathrm{Bu}$ Yulia masih relatif muda.

5. Faktor Lain, Jumlah peserta yang menurun kehadirannya kemungkinan juga disebabkan faktor-faktor lain yang belum teridentifikasi. Kemungkinan faktor-faktor lain tersebut diantaranya karena malas, kurang motivasi,

$$
\text { Ekonomi, Sosial dan Budaya }
$$


berharap mendapatkan bantuan modal maupun alat, kurang berminat dan lainnya.

\section{Hasil Pelatihan dan Pendampingan}

Peserta Pelatihan Fasilitasi Inkubasi Usaha

Mandiri diharapkan mampu mulai melakukan produksi dan memasarkan produknya. Peserta dibimbing untuk memulai mencari konsumen baik perorangan maupun toko, warung, koperasi dan tempat lainnya yang dapat membantu menjualkan produk peserta.

\section{Hasil Awal Produksi}

Peserta mulai melakukan produksi pada minggu pertama setelah mengikuti pelatihan keterampilan membuat Sagon Semanggi. Peserta praktek secara kelompok dan ada yang secara perorangan. Praktek pertama hasilnya masih belum layak jual terutama dari segi bentuk, rasa maupun kemasan. Hasil praktek pertama sampai ketiga pada umumnya masih uji coba hanya untuk digunakan sebagai tester kepada keluarga, teman dan tetangga. Sebagian peserta mulai berusaha memperkenalkan produknya dan mencari pelanggan dengan memberikan tester Sagon Semanggi hasil praktek awal-awal ini.

Peserta dari Kecamatan Benowo yang masih aktif terbagi menjadi dua kelompok yaitu Kelompok Bu Yulia dan Kelompok Bu Kasmalik. Peserta pada umumnya tidak memiliki oven sehingga memanfaatkan peralatan yang ada. Kelompok $\mathrm{Bu}$ Yulia memanfaatkan teflon sebagai pengganti oven dan itupun hasil dari meminjam saudara. Sedangkan Kelompok Bu Kasmalik memproduksi Sagon Semanggi menggunakan Oven dari meminjam saudara.

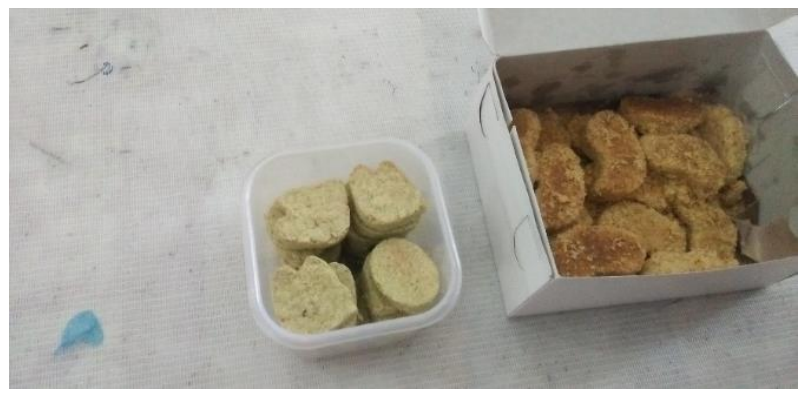

Gambar 22 Hasil Awal Praktek Produksi Sagon Semanggi

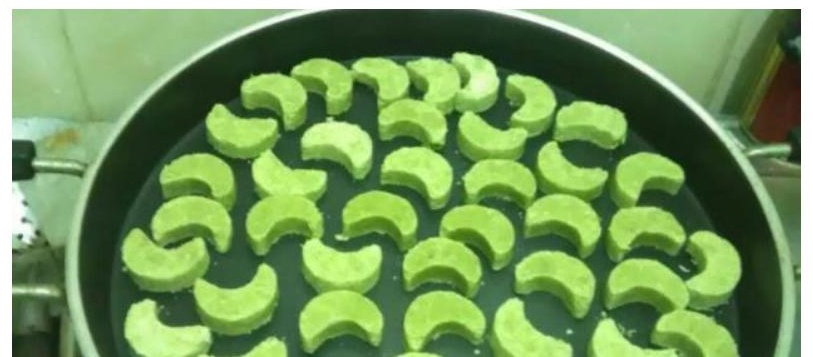

Gambar 23 Produksi Menggunakan Teflon

\section{KESIMPULAN}

Program Fasilitasi Inkubasi Usaha Mandiri ini terdiri dari kegiatan beberapa pelatihan dan pendampingan. Adapun beberapa pelatihan yang telah diberikan kepada peserta terdapat tujuh jenis pelatihan yaitu : 1). Pelatihan Motivasi Wirausaha; 2). Pelatihan Keterampilan; 3). Pelatihan Manajemen Pemasaran; 4). Pelatihan Manajemen Keuangan; 5). Pelatihan Manajemen Organisasi dan SDM; 6). Penyuluhan Legalitas Usaha dan Lingkungan dan 7). Penyuluhan Akses Permodalan

Setelah rangkaian pelatihan selesai kemudian dilanjutkan dengan pendampingan. Pendampingan ini memfasilitasi peserta agar dapat konsultasi terkait hasil mereka mempraktekkan ilmu yang sudah diberikan pada beberapa pelatihan sebelumnya. Disamping menerima konsultasi para narasumber pendampingan juga memberikan tips dan trik untuk mengatasi permasalahanpermasalahan yang dihadapi peserta. Adapun jenis pendampingan yaitu : 1). Pendampingan Manajemen Produksi; 2). Pendampingan Manajemen Pemasaran; 3). Pendampingan Manajemen Keuangan; 4). Pendampingan SDM; 5). Pendampingan Legalitas Usaha; 6). Pendampingan Lingkungan; dan 7). Pendampingan Akses Permodalan

Peserta Inkubasi Bisnis ini sangat antusias. Rata-rata mereka yang hadir mengkuti proses pelatihan maupun pendampingan dari awal sampai akhir tidak ada yang pulang sebelum acara selesai kecuali yang ada kepentingan seperti menjemput anak atau mau ke dokter. Beberapa manfaat yang diperoleh peserta berdasarkan pengamatan naraumber, kesaksian peserta maupun informasi dari

$$
\text { Ekonomi, Sosial dan Budaya }
$$


ketua paguyuban rusun, yaitu : 1. Peserta memiliki motivasi untuk meningkatkan perekonomian keluarganya sehingga bersedia mengikuti program inkubasi ini; 2. Peserta mampu memulai mengembangkan jaringan distribusinya terbukti meningkatnya omset beberapa kelompok karena mendapat pelanggan baru; 3. Penghuni Rusun memiliki kegiatan produktif yang menghasilkan uang sehingga membuat mereka lebih bersemangat; 4. Berkurangnya kegiatan tidak produktif dilingkungan rusun karena beberapa diantaranya menjadi sibuk produksi dan memasarkan produknya; 5. Kreatifitas peserta meningkat terbukti dengan meningkatnya kelayakkan kemasan produk, label dan kualitas produk; 6. Peserta mampu mempraktekkan ilmu yang diperolehnya dari rangkaian beberapa pelatihan dan pendampingan Inkubasi Bisnis ini, terbukti mereka mampu memperoleh omset ratusan ribu hingga jutaan rupiah.

Secara umum Pelatihan dan pendampingan Fasilitasi Inkubasi Usaha Mandiri berjalan baik dan lancar. Meskipun ada penurunan dari jumlah peserta yang mendaftar dengan peserta yang mengikuti pelatihan maupun pendampingan. Beberapa narasumber melakukan identifikasi terhadap penyebab menurunnya kehadiran tersebut. Identifikasi dilakukan dengan cara menggali informasi dari peserta yang aktif melalui wawancara dan secara langsung mendatangi ke tempat peserta yang tidak aktif. Berikut ini beberapa faktor penyebabnya : 1). Bekerja, beberapa peserta terkendala untuk menghadiri pelatihan karena kerja. Semula mereka berharap pelatihan diadakan pada hari libur atau diluar jam kerja. Karena pelatihan dilaksanakan pada jam kerja sehingga mereka tidak dapat menghadiri pelatihan; 2). Mengasuh Anak atau Cucu, peserta yang sudah mendaftar dan terkendala harus mengasuh anaknya yang masih balita atau Nenek yang mengasuh cucunya karena orang tuanya bekerja juga tidak bisa aktif menghadiri pelatihan, diantaranya ada yg tidak pernah hadir pelatihan dan ada yang hadir hanya sekali; 3). Mengharap Uang Saku atau Modal, beberapa peserta mengharapkan dapat uang saku setiap mengikuti pelatihan atau bahkan mendapatkan modal usaha. Karena diawal diinformsikan bahwa tidak ada uang saku dan bantuan modal usaha maka beberapa peserta tidak hadir pada pelatihan-pelatihan berikutnya; 4).
Mengantar Sekolah, peserta yang memiliki anak sekolah masih kecil terutama usia Taman Kanak Kanak (TK) harus mengantarkan sekolah bahkan menunggunya hingga jam pulang sekolah sehingga tidak dapat menghadiri pelatihan; dan 5). Faktor Lain, jumlah peserta yang menurun kehadirannya kemungkinan juga disebabkan faktor-faktor lain yang belum teridentifikasi. Kemungkinan faktorfaktor lain tersebut diantaranya karena malas, kurang motivasi, kurang berminat dan lainnya.

Pada dasarnya setiap peserta yang memulai usaha secara individu maupun secara berkelompok sudah mampu bekerja sama dan memiliki toleransi yang baik. Meskipun terdapat sedikit permasalahan yang timbul namun secara umum tidak begitu mengganggu proses usaha peserta. Adapun permasalahan-permasalahan yang timbul yaitu; 1). Persaingan Kurang Sehat, terdapat kelompok sesama produksi Kerupuk yang menghambat kelompok lain dengan cara mengganggu proses produksi kelompok lain yang dianggap lebih cepat meningkat omsetnya; 2). Konflik Internal Kelompok Usaha, munculnya masalah pada beberapa kelompok usaha yang belum mampu membangun kerja sama yang baik dalam kelompoknya. Sehingga terdapat anggota yang kurang aktif namun menginginkan hasil dari usaha kelompoknya. Atau terdapat anggota yang memaksakan kehendak karena belum terbiasa bekerja secara tim sehingga menimbulkan ketidaknyamanan anggota lain; 3). Aktif Tapi Pasif, terdapat sedikit peserta yang aktif mengikuti pelatihan hingga pendampingan namun sangat kurang dalam mempraktekkan ilmu yang sudah diberikan sehingga penghasilannya tidak ada peningkatan; dan 4). Kendala Alat Produksi, untuk memulai usaha ini peserta membutuhkan bahan baku dan alat untuk produksi. Harga alat yang lebih mahal dibanding bahan baku yang dibutuhkan menjadi kendala tersendiri. Namun demikian dapat diatasi dengan memanfaatkan alat seadanya yang dimiliki oleh anggota kelompok usaha atau pinjam kepada saudara dan pada akhirnya mereka mampu membeli dari hasil usaha yang mulai menghasilkan omset.

\section{UCAPAN TERIMAKASIH}

Ucapan terimakasih disampaikan kepada Dinas Pengendalian Penduduk, Pemberdayaaan

$$
\text { Ekonomi, Sosial dan Budaya }
$$


Perempuan, Perlindungan Anak Kota Surabaya, Lembaga Penelitian dan Pengabdian kepada Masyarakat Universitas Wijaya Putra, Fakultas Ekonomi dan Bisnis Universitas Wijaya Putra dan Pusat Pengembangan dan Penelitian Ekonomi dan Bisnis (BEDRC) FEB-UWP.

\section{REFERENSI}

\section{$-$}

